Z. klin. Chem. u. klin. Biochem.

7. Jg., S. 130-132, März 1969

\title{
Porphyrins in Calcareous Structures with Special Reference to Bones from Porphyric Cattle and Swine
}

\author{
By T. K. Wirth \\ From the Central Laboratory of the Centralsygebust Svendborg, Denmark
}

(Eingegangen am 11. November 1968)

Dedicated to Joachim Brugsch on the occesion of his 60th birthday

\begin{abstract}
Bones from porphyric animals are treated first with $40 \%$ sodium hydroxide and subsequently with concentrated hydrochloric acid which dissolves the chalky residue from the alkaline digestion under violent foaming. The porphyrins are precipitated from the acid solution at $\mathrm{pH}$ ca. 3 together with calcium salts and subsequently washed and dissolved in about $50 \%$ acetic acid. The solution is then diluted with an approximately equal volume of water and the $\mathrm{pH}$ adjusted to ca. 3 , after which the porphyrins are adsorbed on to a talc filter. After washing, the porphyrins are eluted with sulphuric acid-methanol and subsequently extracted with chloroform as their esters. Thin layer chromatographic analysis of the ester crystals and mother liquors showed the presence of both uro- and coproporphyrin and a series of intermediary porphyrins in bones from porphyric cattle and pigs.
\end{abstract}

Knochen porphyrischer Tiere wurden mit 40proz. Natronlauge und dann mit konz. Salzsäure behandelt, die den kreideartigen Rückstand der alkalischen Hydrolyse unter heftigem Schäumen auflöste. Die Porphyrine wurden aus der sauren Lösung bei etwa pH 3 zusammen mit Calciumsalzen ausgefällt, dann gewaschen und in etwa 50proz. Essigsäure gelöst. Die Lösung wurde mit etwa dem gleichen 'Volumen Wasser verdünnt und der $\mathrm{pH}$ auf etwa 3 gestellt. Anschließend wurden die Porphyrine an ein Talkfilter adsorbiert, gewaschen, mit Schwefelsäure-Methanol eluiert und darauf als die entsprechenden Ester mit Chloroform extrahiert. Die dünnschichtchromatographische Analyse der Esterkristalle und Mutterlaugen zeigt das Vorkommen sowohl von Uro- als auch Koproporphyrin und einer Anzahl von internediären Porphyrinen in den Knochen porphyrischer Rinder und Schweine.

The isolation of porphyrins from porphyric bones is a time-consuming and tedious procedure according to existing publications $(1,2)$ and the methods proposed to extract porphyrins from shells are not much better $(3,4)$. These methods for bones employ crushing and defatting before the extraction and the demonstration that the de-fatting could be omitted was an advance (5). Our experiences with bones from porphyric swine (6) and cattle (7) have shown that the preparation from bones can be much simplified, and the same simplifications should be applicable to other calcareous structures like shells. Further, chromatographic analyses of the bone porphyrins of porphyric cows from Denmark (7) and of a skeleton of a porphyric pig placed at the author's disposal by Dr. G. KelÉNYr, Department of Pathology, University of Pécs, Hungary were performed with the talc thin layer method introduced by Wirh $(8,9)$. The simplified methods employed are described below.

The bones were first treated with $40 \%$ sodium hydroxide in 5 litre plastic beakers $-1 \mathrm{~kg}$ bone for every 2 litres sodium hydroxide. The only crushing required is to enable the fragments to be completely covered with the fluid, and if part of a bone is above the fluid surface it can easily be pushed down after the digestion has begun when the lower part of the bone becomes sufficiently fragile. After about one week's digestion in the strong alkali the protein part of the bone is largely dissolved, and the material is ready for acid extraction. In the case of shells this initial alkaline digestion can be omitted, because the protein content of shells is much lower than that of bones. During the alkaline digestion it is necessary to stir the digestion mixture once or twice daily, most conveniently with a gloved hand which permits simultaneous crushing of the mollified bone mass continuously during the digestion.

When the alkaline digestion has reached a stage where only a coarse powder and small bone fragments are left, and this is the case after about one week's digestion with repeated mixing as described, the fluid is removed by decanting and the bone powder washed with distilled water until the alkali has been removed. Only minor amounts of porphyrins are extracted into the alkaline soup and the composition of the porphyrin present there does not diverge from that found in the acid bone extracts according to thin layer chromatographic studies.

The washed alkali-digested porphyric bones form a pink coarse powder. The next step is to dissolve this powder in concentrated hydrochloric acid in one or more 5 litre plastic beakers. The dissolution proceeds under violent foaming due to $\mathrm{CO}_{2}$-formation and must be performed with caution to avoid "boiling-over". The acid extract is collected by decanting and filtered through a large Büchner funnel (e. g., $26 \mathrm{~cm}$ of diameter) into .a 5 or 10 litre suction flask. The filter paper used must be hard and acid resistant, e. g. Whatman No. 50. After decantation and filtration more acid is poured into the remaining bone powder in the beaker and the procedure is repeated until no more is dissolved. Only small insoluble remains are left which do not show any red fluorescence in Wood's light and therefore cannot contain significant amounts of porphyrin.

The filtered acid extracts are subsequently adjusted to $\mathrm{pH}$ about 3 (universal indicator paper), most conveniently with concentrated ammonia and glacial acetic acid. During this a heavy pink precipitate forms which is subsequently collected on a Büchner funnel and washed repeatedly on the funnel with distilled water. Then the 
washed calcareous precipitate is extracted in a 5 litre plastic beaker with $50-80 \%$ acetic acid, one to several litres according to the quantity of precipitate. In this way the precipitate with the porphyrin is dissolved and only a small residue which does not cxhibit red fluorescence in Wood's light remains.

The next step is to adsorb the porphyrin from the acetic acid on to talc. First an equal volume of distilled water is added and conc. ammonia to $\mathrm{pH}$ ca. 3 (universal indicator paper). A talc filter of ca. $10 \mathrm{~mm}$ thickness is prepared on the Büchner funnel by pouring on an appropriate talc suspension under suction. The most beautiful talc surfaces are obtaincd from suspensions of talc in methanol. Ordinary talc of pharmacopoiea quality is used. After appropriate washing of the talc filter with distilled water the diluted acetic acid solution is sucked through the talc.

In this way the porphyrins present are adsorbed on the talc filter which is subsequently washed by sucking $2-3$ litres of distilled water through the filter. If the filtrate exhibits red fluorescence in Wood's light a second adsorption through another filter is required. The filter is dried by continuing the suction for a period after the washwater has passed.

Then follows elution and esterification of the porphyrin by sucking $5 \% \mathrm{v} / \mathrm{v}$ sulphuric acid/methanol through the Büchner funnel until the filtrate becomes colourless. The first of the filtrate is discarded and collection begins when the colored eluate starts to pass. The amount of elution fluid required depends on the amount of starting material and for about one $\mathrm{kg}$ of bones between half and one liter of sulphuric acid/methanol is required.

$\Lambda$ fter standing overnight esterification is complete and the ester can be extracted with chloroform in the usual way, followed by chromatographic purification and crystallization of the porphyrin estcr from chloroform-methanol (cf. e. g., WrrH 10, 11).

The chromatographic methods were those introduced by the writer $(8,9)$ employing thin layers of talc. Both the crystals and the mother liquor were subjected to hydrolysis for 48 hours with $7 \mathrm{~N} \mathrm{HCl}$ and then subjected to talc thin layer chromatography with a mixture of 2 volumes of $0.5 \mathrm{~N} \mathrm{HCl}$ and 3 volumes of acetone. Further, the esters themselves were chromatographed on talc plates with a mixture of equal volumes of pyridine, glacial acetic and acetone. This method for the free porphyrins and that for esters, which has not previously been published, gave the same results.

A black and white photo af a talc plate in Wood's light is seen in Figure 1. For photographic data see WIrH (9).

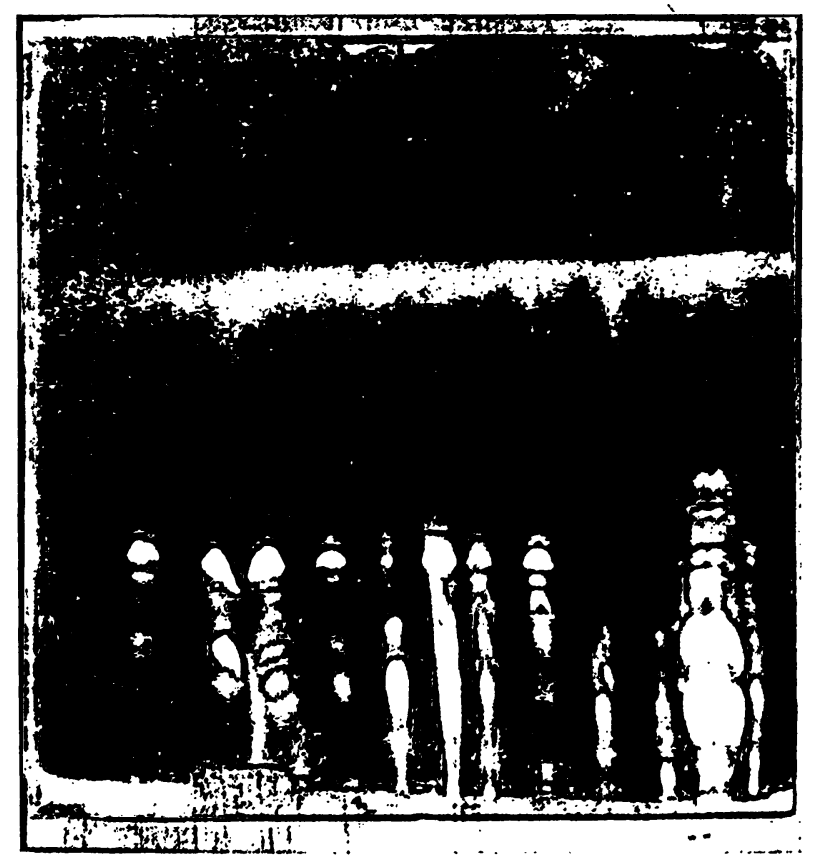

Fig. 1

Thin layer chromatogram of porphyrins
Chromatogram No. 1 from the left is porphyrin from pig bones as obtained by hydrolysis of crystals. The only porphyrin present apart from traces is uroporphyrin. No. 2 chromatogram from the left is obtained from an hydrolyzate of evaporated mother liquor from the pig bone crystals. Here considerable amounts of coproporphyrin are present besides the uroporphyrin. Chromatogram No. 4 is from the crystals obtained from a porphyric cow's jaw and, like the crystals from the pig bone, it contains practically only uroporphyrin. Chromatogram No. 3 is the corresponding mother liquor which contains coproporphyrin and some intermediary porphyrins besides uroporphyrin. Chromatogram No. 5 from the left is a marker prepared from crystalline esters from bovine porphyria urine and containing 4- and 5-carboxyl porphyrins. Chromatogram No. 6 and 7 are from hydrolyzed ester extracts from the "alkaline soup" from the bone extraction, No. 6 corresponding to a heavier load of material on the starting spot than No. 7. This rather impure extract is seen to exhibit spots corresponding to coproporphyrin and uroporphyrin as well as an intermediary porphyrin, most likely 5-carboxylic porphyrin. Chromatogram No. 8 from the left is from hydrolized crystals of Waldenström ester from human porphyria urine and shows spots of 8-, $7-$ and 6-car-boxyl porphyrins. Chromatogram No. 4 from the right is the same preparation as No. 5 from the left, applied on the starting spot in a less heavy load.

Chromatogram No. 2 from the rigth is from the chromatographic column of alumina used for preparation of the raw ester from the pig bone. After elution of this column with chloroform-methanol significant quantities of porphyrin ester are retained on the column which can be extracted with $5 \mathrm{~N} \mathrm{HCl}$ from the alumina after evaporation of the chloroform and methanol. This porphyrin was hydrolyzed, precipitated and re-esterified and then subjected to thin layer chromatography. A series of porphyrins are seen to be present, mostly 4and 5-carboxyls. The spots in advance of the uroporphyrin position are not fluorescing red in Wood's light but exhibit a greenish fluorescence, but are recorded on the black- and white photo. Chromatogram No. 1 from the right is the same as No. 2 but the load of porphyrin on the starting spot is less heavy. Chromatogram No. 3 from the right corresponds to the mother liquor obtained from the crystals corresponding to No. 2 and shows the most pronounced spot in the lower carboxyl region below the copro spot. Whether it is 3- or 2-carboxyl cannot be decided as the talc-acetone$\mathrm{HCl}$ thin layer chromatography is not suitable for distinguishing between lower carboxyls at least if 3 vol. acetone and 2 vol. $0.5 \mathrm{M} \mathrm{HCl}$ is employed. With 7 vol./ 3 vol. a higher $R_{\mathrm{F}}$ and better separation in the lower carboxyls is achieved.

Figure 1 shows the efficiency of the talc-acetone- $\mathrm{HCl}$ thin layer chromatography in porphyrin analysis in bones. The plate photographed is a $180 \times 180 \mathrm{~mm}$ plate of $0.25 \mathrm{~mm}$ talc thickness prepared in a Desaga 
apparatus and run for 90 minutes in a Desaga tank. We have later found that $70 \times 70 \mathrm{~mm}$ plates of $0.30 \mathrm{~mm}$ talc thickness give a separation nearly as good as the large plates during a 10-15 minutes' run, and that development with 7 vol. acetone and 3 vol. $0.5 \mathrm{M} \mathrm{HCl}$ gives clear separation of 7- and 8-carboxyls and can usually be achieved in one 10 minutes run.
We have also used the method described for large scale preparation of uroporphyrin from the skeleton of a porphyric cow and a porphyric calf and found it to work satisfactorily.

My thanks are due to Dr. G. KelÉnYI, Department of Pathological Anatomy, University of Pécs, Hungary for bones from a porphyric pig. Mrs. Kamma Wrris is thanked for valuable technical assistance.

\section{References}

1. Fischer, H., H. Hilmer, F. Lindner and B. Pürzer, HoppeSeylers Z. physiol. Chem. 150, 44 (1925). - 2. Rimington, C., Onderstepoort J. Vet. Sci. Animal Husbandry 7, 567 (1936). 3. Comfort, A., Science Washington 112, 279 (1950). - 4. KeNNEDY, G. Y., Scand. J. Clin. Laborat. Invest. 8, 79 (1956). 5. With, T. K., A. Clausen and N. J. HøjgaArd-Olsen, 310. Beretning fra forsogslaboratoriet, Rolighedsvej 25, Copenhagen (310. report from the Royal Danish Agricultural Experiment
Statiøn, Copenhagen. English Summàry.) (1959). - 6. JørGENSEN, S. K, Brit. Veterinary J. 115, 160 (1959). - 7. JøRGENSEN, S. K., Brit: Veterinary J. 117, 1 and 61 (1961). - 8. Wrre, T. K., Clin. Biochem. (Montreal) 1, 30 (1967). - 9. WrTH, T. K., Ugeskrift f. Lxger (Copenhagen) 130, 641 (1968). - 10. WITH, T. K., Biochem. J. 68, 717 (1958). - 11. WITH, T. K., Dan. Med. Bull., in press.
Prof. Dr. Torben K. With The Laboratory, Svendborg Country Hospital DK 5700 Svendborg, Denmark 